\title{
Clio
}

Women, Gender, History

37 | 2013

When Medicine Meets Gender

\section{Medicine and sexuality, overview of a historiographical encounter: French research on the modern and contemporary periods}

Sylvie Chaperon and Nahema Hanafi

Translator. Regan Kramer

\section{OpenEdition}

\section{Journals}

Electronic version

URL: http://journals.openedition.org/cliowgh/396

DOI: $10.4000 /$ cliowgh.396

ISSN: 2554-3822

Publisher

Belin

\section{Electronic reference}

Sylvie Chaperon and Nahema Hanafi, « Medicine and sexuality, overview of a historiographical

encounter: French research on the modern and contemporary periods », Clio [Online], 37 | 2013, Online since 15 April 2014, connection on 19 April 2019. URL : http://journals.openedition.org/cliowgh/396 ; DOI : 10.4000/cliowgh.396 


\section{Current Research}

\section{Medicine and Sexuality, overview of a historiographical encounter: French research on the modern and contemporary periods}

Since the 1980s, the history of medicine in France has undergone a major renewal of its approaches, subjects and narratives. Women's history, gender history and the history of sexualities, which have all been expanding rapidly over this same period, have contributed significantly to this renewal by focusing on medical sources that had been ignored by traditional history of medicine. Pervaded with the positivist attitude inherited from the $19^{\text {th }}$ century, the history of medicine, like the history of science in general, had for many years produced a series of narratives about the progress of knowledge, leading from great men and major discoveries to the scientificallyrecognized truths of the contemporary era, while shunting mistakes, obscurantism and obsolete theories to the ignored margins.

Being relatively self-contained, these narratives tended to ignore or minimize the social, political, and ideological influences that were woven into and informed scientific discourse, focusing instead on the epistemological advances made possible by progress in theoretical 
thinking or technology. ${ }^{1}$ Over the last thirty-odd years, and due to a range of factors (the challenges to medical authority, and critiques of the history of science by sociologists, anthropologists and philosophers) "traditional history of medicine gradually made way for a social and cultural history of sickness and health". ${ }^{2}$ Our aim here, however, is not to trace all of these many evolutions; we will limit ourselves to the example of sexuality. The word, which first appeared (in French) in the 1830s, had a range of different meanings. It was used variously to refer to sexuation (differentiating the sexes), procreation, and eroticism. Historically, these three meanings have tended to become dissociated. We will use it here strictly in the sense of practices and discourses pertaining to sexual pleasure, a definition which excludes broad fields of research into birth control, childbirth, and medical beliefs about the differences between the sexes. By limiting our scope to the modern and contemporary periods, we should like to focus on the pioneers of the encounter between history and medicine and the history of sexuality, stricto sensu: their questions and conjectures, and the sources they used.

\section{The Pioneers: Historians from the 1970s}

Recently, while being interviewed by Baptiste Coulmont and Marianne Blidon, Michel Bozon declared that: "In France, you can't say that academic interest in sexuality started with feminists or the homosexual-rights movement, as is often said about the USA. Historians like Philippe Ariès, Jean-Louis Flandrin and Alain Corbin were the key figures. ${ }^{3}$ " This assessment, which needs to be qualified somewhat, is nevertheless relevant. Researchers' interest in sexuality was undoubtedly stimulated by protest movements related to sexuality - with feminist and homosexual-rights campaigns at the forefront - but it is also true that it took a long time for the feminist

1 For an overview of these changes in the history of the sciences in general, see Pestre 1995; for a historiography that is more focused on medicine in particular, see Jones 1987, Porter \& Wear 1987, Velle 1998.

2 Velle 1998: 161.

3 Coulmont \& Blidon 2010. 
studies and gay and lesbian studies that developed in their wake to affect French academic spheres, which remained impermeable.

In the early 1960s-1970s, the history of sexuality, or of "sexual behavior" was still primarily studied through the prism of historical demography, which recorded numbers of unmarried couples, age at marriage, birth and marriage rates, and intergenesic intervals, but above all sought to explain the early drop in the French birth rate 4 . This opened up various avenues of investigation, to which historians of mentalities flocked. In the wake of that research, a new generation of historians, influenced by the sexual campaigns of the 1970s, pioneered the history of sexuality (in the narrow definition we have adapted), in response, one could say, to Alain Corbin's request in the introduction to his book Les Filles de noce (1978) (later translated as "Women for Hire"): “... it's about time that historians of contemporary France should be able to go into couples' bedrooms without being accompanied by someone from the registry office. 5 " In France, Philippe Ariès, Jean-Louis Flandrin, Alain Corbin, as well as André Bejin, Pierre Darmon, Yvonne Knibiehler and Georges Lanteri-Laura, led the way in this new history of sexuality.

Source materials from moral theology were often drawn upon to support the theory, in the wake of work by Norbert Elias (1969) and Jos Van Ussel $(1972)^{6}$, that between the $16^{\text {th }}$ and the $18^{\text {th }}$ century, sex drives were repressed.6 Although he did draw attention to some forms of pre-marital sexuality, Jean-Louis Flandrin made abundant reference to these sources in both L'Église et le contrôle de naissances (The Church and Birth Control) (1970) ${ }^{7}$ and in his later work. The issue of Annales ESC (1974) entitled "History and Sexuality", edited by André

4 Cf. particularly the work about birth control edited by Helène Bergues, with contributions from Philippe Ariès, Louis Henry and Alfred Sauvy, Bergues 1960.

5 Quoted by Corbin 2000: 41.

6 It should be noted that John Van Ussel refers to the medical point of view about masturbation, which he contrasts with that of moral theology.

7 Flandrin 1970. This book is directly influenced by the research of the American jurist and theologian John Noonan, cf. Noonan 1966. Several references to doctors or to major medical evolutions to the theologians' point of view are worth noting. For Jean-Louis Flandrin's contribution to the history of sexuality, cf. Corbin 2003. 
Burguière, returned to the hypothesis of repression, leaving the medical viewpoint on the sidelines, and focusing once again on demographic studies, religious interpretations and legal sources. Philippe Lejeune's contribution, however, was an exception to this rule, no doubt because he was dealing with one of the subjects that led historians to examine medical sources: masturbation. ${ }^{8}$ Referring to Jean-Jacques Rousseau's masturbatory confession, he studied Samuel-Auguste Tissot's L'Onanisme and recalled Tissot's influence on $19^{\text {th }}$-century French and German doctors. In an even more novel way, he examined the relationship between the philosopher and the doctor, by analyzing the shame of the confession and Jean-Jacques Rousseau's refusal to connect his masturbation with his later troubles. Attentive to writing about the self, which lay at the heart of his research, Philippe Lejeune pointed the way towards studying how medical precepts in terms of sexuality are received, although that path would not be followed for several decades more.

The influence of Michel Foucault's La Volonté de savoir (1976) [The Will to Knowledge ] - the absolute reference in both Britain and the USA - was not particularly decisive in France, at least not at first. Michel Bozon, in the above-mentioned interview, considers that: “...perhaps Foucault's propositions about sexuality have had a much larger impact in the United States than in France because they represented a greater novelty there, since the habit of "deconstructing" categories and institutions from a historical point of view was not highly developed there yet."

The theory that the ubiquitous appeal to "Saint Foucault" in the United States corresponded to a kind of legitimation strategy for the burgeoning field of gay and lesbian studies is an attractive one. ${ }^{10}$ All the same, Michel Foucault's work on the genesis of a scientia sexualis and his considerations on bio-politics also opened up the way to a variety of approaches later adopted by a large number of historians, in France and elsewhere: female desire, through the "hysterization" of women's bodies, solitary sexuality, and consequently the

\footnotetext{
$8 \quad$ Lejeune 1974: 1015-1021.

9 Coulmont \& Blidon 2010.

10 Halperin 2000 [1995].
} 
pathologization of sexuality and the "pedagogization of children's sex," eugenics and hence the control of procreative practices, as well as the psychiatrization of perverse pleasures, via the elaboration of a nosology (classification) of sexual problems. ${ }^{11}$ His rejection of the repression theory, as well as his insistence on the connection between discourse and power were also widely adopted. His work further led to the greater recognition of medical sources for the history of sexuality, and historians began to use them more frequently by the late 1970s.

For women's history, which was beginning to emerge at that time as well, the study of medical theories offered an opportunity for highlighting the "naturalization" of women, based on anatomical and physiological descriptions and analyses indicating an incommensurable sexual difference. ${ }^{12}$ Since her earliest articles on women's history (1976), Yvonne Knibiehler has also long been concerned with the question of women's apprehension of sexuality, their experience of sexual desire, pleasure and procreation. It was while writing her thesis on François Mignet, which she began in 1964, that she became a feminist - first upon learning about the tribulations of Princess Belgiojoso, and then by reading Engels, Bebel and Beauvoir. Yvonne Knibiehler was determined to demonstrate the depth and value of medical sources (particularly dictionaries), which she used to analyze both the putative difference between the sexes and women's inferiority - and sexuality. ${ }^{13}$ She drew on them extensively in her many books and articles devoted to the history of motherhood, fatherhood, sex education, social workers, nurses and women in the colonies ${ }^{14}$.

The same themes of generation, women, and more generally of sexuality drew the attention of Pierre Darmon, a former research director of the Centre Roland Mousnier at the CNRS. His position is

11 Foucault 1976: 137. Cf. particularly - and with no claim of being exhaustive - the works of Anne Carol, Nicole Edelman, Sabine Arnaud, Thomas Laqueur. See also Artières \& Da Silva 2001.

12 Borie's pioneering work (1973) should be mentioned here.

13 Knibielher 1976a and 1976b; Knibielher \& Marand-Fouquet 1980.

14 See Bernos \& Bitton 2004. 
an anomalous one. A multi-facetted historian, he opened up several paths in the history of sexuality, yet he has been singularly underrecognized by his peers. With Le Mythe de la procréation à l'âge baroque (1977), Le Tribunal de l'impuissance, virilité et défaillances conjugales dans l'ancienne France (1979) and Mythologie de la femme dans l'ancienne France, XVIe-XVIIIe siècle (1983), he could be described as specialist in the medicalization of sexuality - had he not published on a range of other subjects as well (the history of smallpox and cancer, and Pasteur - but also criminology, Algeria, the Great War, cinema during the Occupation, and more). While most of his first book was devoted to the "baroque" science of generation, its first chapter, "The Instruments of Procreation", outlined a history of the penis and its erection, as well as of the clitoris, based on medical treatises. All of these ideas would be reprised considerably later by a new generation d'historians ${ }^{15}$. Was it because of those risqué pages that the book was first published by Jean-Jacques Pauvert, a publisher known for having fought against censorship of pornography? At any rate, Darmon's study was republished four years later by the more mainstream publisher Seuil, as were his later books. Based on a thesis directed by Robert Mandrou, Darmon's Le tribunal de l'impuissance ("The Tribunal of Impotence"), was based largely on medico-legal procedures in court cases pronouncing marriage annulments. Darmon reiterated his interest in sexuality through medical sources in his re-edition of $\mathrm{La}$ femme criminelle et la prostituée (1991) by the 19th-century Italian physician and criminologist Cesare Lombroso, ${ }^{16}$ shedding light on criminal anthropology's views of female sexuality and prostitution.

The history of sexuality also owes a lot to literary historians who began to study erotic and pornographic literature, but who also turned to medical texts in the late 1970s. For the most part, they revisited writings from the modern period, in particular the eighteenth century. Jean-Marie Goulemot, for instance, proposed a new edition of Nymphomania, or a Treatise on Uterine Fury by the physician M. D. T. Bienville ([1771] 1980) ${ }^{17}$. Goulemot also edited

\footnotetext{
15 Laqueur 1989; Park 1997; Chaperon 2012b.

16 Lombroso 1991.

17 Bienville 1980 [1886].
} 
the "Representations of Sexual Life" issue of the journal Dix-huitième siècle (1980), based on seminars at the University of Paris VII in the years 1974-1976, as well as on the conference "L'Amour en France" (1977). Of the twelve contributions to that issue, four are based on medical sources; and most of them refer to Michel Foucault's works. Some of them draw on literary texts - in particular obscene publications, as well as works of medical popularization and marriage manuals (Venette and Lignac) ${ }^{18}$, or even anatomical diagrams (Gautier-Dagoty) ${ }^{19}$. Marginal sexualities prompted the greatest interest among the authors: hermaphroditism (Michel Delon), nymphomania (Jean-Marie Goulemot) ${ }^{20}$ and masturbation (Theodore Tarczylo) ${ }^{21}$, because these were the subject of a medical discourse which implicitly reasserted sexual norms. In that collection, literary historians were the ones who made most use of medical sources, revealing the wealth of information they contain.

Contributors to the very successful "Western Sexualities" issue of the journal Communications (1982) - it was translated into several languages - focused essentially on religious discourse ${ }^{22}$. That also applies to Michel Foucault, who submitted an article on chastity in the works of Cassius, which was to form part of the third volume of his Histoire de la sexualitée 23 Based on Philippe Ariès's seminar at the

18 Delon 1980.

19 Guicciardi 1980.

20 Goulemot 1980.

21 Tarczylo 1980, cf. also Tarczylo 1983 in which the author intertwines religious, medical and literary discourses on masturbation.

22 Philippe Ariès mentions love, marriage and homosexuality with extremely marginal references to medical sources, cf. Ariès 1982. Jean-Louis Flandrin, who contributed to both special issues (the journals Dix-buitième siècle and Communications) cites moral theology only when detailing sexual positions. In Le sexe et l'Occident (1981) in which he aims to write a "history of sexuality," he studies fiction and popular proverbs, but without taking the evolution of the medical sciences and their influence into consideration. François Lebrun, in La vie conjugale sous l'Ancien Régime (1985), does the same while examining such condemned practices as sodomy and homosexuality. Nevertheless, he does mention medical theories in a short paragraph about masturbation, cf. Lebrun 1985: 95.

23 Foucault 1982. 
EHESS (1979-1980), the journal issue was co-edited by André Béjin, who played a key coordinating role while remaining relatively discreet. A sociologist - he studied with Edgar Morin, who directed his thesis entitled Crises de la société et crises de la sexualité (1975) - Béjin later joined the EHESS's Centre for Transdisciplinary Studies and its journal, Communications. Since then, André Béjin has regularly published articles on the history of sexuality and particularly of sexology; he has also edited new editions of several key works of medical discourse about perversions for the publishers Payot ${ }^{24}$.

We should also stress the major role played by Alain Corbin, who encountered the historical figure of the prostitute while doing research on migrants to Paris from the Limousin region (his thesis, defended in 1973, was initially called "Migrant Limousins, Sedentary Limousins"). He then embarked upon an extensive analysis of mercenary sexuality, based on a wide range of sources, including those produced by doctors who favored regulating prostitution, like the hygienist Alexandre Parent-Duchâtelet ${ }^{25}$. From that time on, he has contributed continuously to the history of sexuality (venereal disease, private lives, and sexual violence) including his recent Harmonie des plaisirs (2009) which is based as much on medical sources as on religious and pornographic ones ${ }^{26}$.

Finally, Georges Lanteri-Laura (1930-2004), psychiatrist and historian of his own discipline, can also be seen as a pioneer of the history of sexual perversions. He resituated the writings of Freud in the psychiatric and psychological context of turn-of-the-century Europe, although without focusing on France in particular ${ }^{27}$.

The new subjects proposed by historians of sexuality in the 1970s attracted interest from the media and from the general public, because they resonated with topics that were then current in France (debates about contraception and abortion; the movements and

24 Béjin 1990 (collected articles); Binet 2001; Krafft-Ebing 2010 and 2011.

25 Béjin 1990; Binet 2001; Kraft-Ebing 2010 and 2011.

26 Corbin 2007. On this theme, see also Robert Muchembled's book, which uses medical sources more marginally, but which, concerning the $19^{\text {th }}$ century, contains a chapter called "La nouvelle religion médicale," Muchembled 2005: 224-227.

27 Lanteri-Laura 1979. 
campaigns of feminists, homosexuals and prostitutes), but they offended some fellow historians, who specialized in more traditional subjects. William Monter, who contributed a study of sodomy in the late modern era to the "History and Sexuality" issue of Annales ESC (1974), pointed out that the theme was still "somewhat taboo in academia, at least among historians" 28 . Pierre Darmon's first two books clearly upset the historical community and received few reviews in scientific journals and none in the major historical ones ${ }^{29}$. Feminist studies, which were really taking off at that time, got a more enthusiastic reception ${ }^{30}$. Even today, Pierre Darmon's contribution to the renewal of medical historiography does not seem to be truly recognized, except perhaps by historians of criminology ${ }^{31}$. "The vast majority of historians were men (...). Several of them became indignant at reading analyses of medical texts about genitals, coitus and orgasm, vapors and hysteria in a scholarly history journal," Yvonne Knibiehler recalls about her first articles ${ }^{32}$.

One can't help noticing that except for Georges Lanteri-Laura, this research was more concerned with the history of heterosexuality and conjugality than with homosexuality, which was considerably more visible in the United States. Homosexuality studies did exist in France, but they were found outside of academia, in activist books and publications. The border between social movements and recognized scientific knowledge is much less permeable in France ${ }^{33}$. In contemporary history, the first doctoral theses were defended in the late 1970s and early 1980s, and were granted scant academic recognition. Marie-Jo Bonnet defended her thesis about love between

29 Except for Roger Darquenne in the Revue belge de philologie et d'histoire (1980, 58/3, p. 741); François-André Isambert, for example, provides only a few very skeptical allusions, in the Archives des sciences sociales des religions (1980, 49/2, p. 248249).

30 See Vandelac 1977.

$31 \mathrm{He}$ is frequently quoted in the articles, files and bibliographies on Criminocorpus:

http://criminocorpus.cnrs.fr/ and http://criminocorpus.revues.org/.

32 Knibiehler 2010: 225.

33 Chaperon 2002. 
women in 197934, while, following the study by Jean-Paul Aron and Roger Kempf: Le Pénis et la démoralisation de l'Occident (1978)35, Christian Bonello and Patrick Cardon examined medical discourse about inversion in the late $19^{\text {th }}$ century (they both defended in 198436 ). None of them had an academic career.

Once these pioneering efforts became known, many others followed. The writings of doctors were chosen as guides for these explorations of the past because, like the clergy, they had sought to supervise their contemporaries' sexuality. Research has taken off in many directions - studying medical prejudice against contraception, the struggles engaged in by doctors against masturbation or other sexual practices deemed deviant, their role in forensic medicine and as expert witnesses about deviances and sexual violence, hygienist doctors' supervision of prostitution, the spread and perception of venereal disease, disorders connected to sexuality (like hysteria), marital counseling, sex education, and more. Within the framework of this short article, it would be impossible to list all the publications that have been enriching knowledge up to the present ${ }^{37}$. In conclusion, we will simply indicate the different ways in which these sources have been used.

\section{Medical Sources: a Gold Mine}

"Medical thought has turned out to be a gold mine, a stunningly rich vein of sources," Yvonne Knibiehler was pleased to report ${ }^{38}$. These sources are indeed extremely abundant and go well beyond the field of health (to which sexuality is considered one of the keys), since doctors offered their enlightened opinions on just about everything. Produced by medical students (theses), by doctors in the course of their regular activities (teaching manuals, scholarly treatises, books aimed at the general public, correspondence, expert witness reports,

\footnotetext{
34 Bonnet 1981.

35 Aron \& Kempf 1978.

36 Bonello 1984; Cardon 2008.

37 For a broader historiographical overview, see Chaperon 2002; Corbin 2003; Rebreyend 2005; Revenin 2007; Tamagne 2007 and Harvey 2010.

38 Knibiehler 2010: 226.
} 
articles for medical journals), and by various institutions (medical schools, hospitals, psychiatric wards, clinics, scholarly societies), as well as by caregivers, patients or laymen and women (recipe books, self-medication books, epistolary consultations), these sources are both varied and innumerable. All of these different types of documents have been pressed into service to compose a history of sexuality based on medical viewpoints, complementing the religious, literary and judicial sources, as well as private writing.

Initially concerned with tracing the progress of knowledge, medical historians have essentially used printed sources like theses, dictionaries, and major treatises that summarized medical knowledge, as well as books intended for the general public. These have been of particular interest to historians of conjugal sexuality, who studied the advice given to spouses to facilitate generation and produce healthy children, preferably males ${ }^{39}$. Yvonne Knibiehler and Alain Corbin were the first to provide a comprehensive overview of sources for conjugal hygiene, particularly for the $19^{\text {th }}$ century ${ }^{40}$. Certain texts dating from the late $18^{\text {th }}$ century have been discussed endlessly by historians, especially Samuel-Auguste Tissot's Onanisme and Bienville's La Fureur uterine ${ }^{41}$. These medical publications also fed a debate about the limits of the speakable, and the use of Latin or French, for example, to refer to sexuality ${ }^{42}$. Research focused on the dynamics of professionalization and specialization has relied more on professional journals, and on the work of the learned societies which proliferated throughout the $19^{\text {th }}$ and $20^{\text {th }}$ centuries. Historians of sexual perversions (which included homosexuality) soon identified works by professors of forensic medicine, psychiatric expert

39 Cf. particularly Fischer 1991.

40 Corbin 1984; Knibiehler 1980 and 1996.

41 Cf. esp. Tarczylo 1980 and 1983; Stengers \& Van Neck 1998; Carol 2002, Laqueur 2005; Wenger 2005.

42 Cf. Bracher 2012, and the special issue " Pudeurs... ", Histoire, médecine et santé, Spring 2012. 
witnesses and criminologists, who were responsible for this "medical appropriation. ${ }^{43}$ "

Historians have noted the intense gender asymmetry in these sources. Produced by men (women did not enter medicine until quite late), they tell us more about male domination than about women's condition. In addition, these sources tend largely to ignore the views of patients (whether sick or well) about the medicalization of sexuality and their own sex lives.

In Britain, the emergence of a history of medicine "from below," which includes laypersons' representations and practices, owes much to the work of Roy Porter, carried out in the 1980s. His work had a relatively late influence on French-language history of sexuality ${ }^{44}$. It wasn't until the mid-1990s that historians began to pay attention to different "writings about the self," in connection with a growing interest in private writings, thereby overthrowing the asymmetry caused by the abundance of professional sources. Daniel Teysseire's study, Obèse et impuissant (Obese and Impotent) (1995) ${ }^{45}$ is representative of this concern for rediscovering first-person, lived sexual experience. Based on epistolary consultations sent by the lawyer Elie de Beaumont to the doctor Samuel-Auguste Tissot, the author examines the sexual frustrations of a man who desired a second son, but was pressed for time by his wife's advancing age and fettered by his own impotency. These sources, which were then picked up by other historians ${ }^{46}$, made it possible to study the role of sexuality in the therapeutic relationship, as well as everyday practices and how they were experienced, ways of speaking or keeping silent, recognition of

43 Aside from the previously mentioned work of Lantéri-Laura, Bonello and Cardon, we could also refer to Rosario 2000, Oosterhuis 2000, Tamagne 2000, Murat 2006 and Chaperon 2012a.

44 Porter 1985; Porter \& Teich 1994.

45 Teysseire 1995.

46 On the epistolary consultations sent to Auguste-Samuel Tissot connected to sexuality, cf. Stolberg 2000, Barras 2005, Pilloud 2008, Hanafi 2012. Many other archives of epistolary consultations exist, which would be worth studying from this angle. 
caregivers' skills in this field, and the impact of professional discourse on practice $^{47}$.

Doctors also encouraged their patients or "deviants" to write their own autobiographies. Philippe Artières has methodically explored "gutter" writings," particularly those from the archives of Lacassagne, the doctor who founded the French School of Criminology: correspondence with "inverts," criminals' autobiographies, collections of song lyrics, slang dictionaries, writings by inmates in Saint Paul Prison in Lyon, collections of palimpsests and tattoo tracings. These sources, produced by the object of knowledge who has become an agent of knowledge, have greatly contributed to reflections about agency, subjectivization, and the crossroads of power, resistance and consent ${ }^{48}$.

This renewal of the history of medicine from below invites us to relativize doctors' influence on their contemporaries; lay people, both men or women, might challenge, adapt or get around the theories... when they didn't just out and out ignore them.

Certain sources, at the intersection of learned and lay knowledge, would bear looking at again, especially collections of medicinal recipes and advertisements for therapeutic products. The former, essentially found within the domestic sphere, pose the question of everyday knowledge being applied to peoples' sex lives ([in]fertility, venereal disease, etc.) and how it articulated with medical competency for that field. Advertisements developed later, along with the press, from the $18^{\text {th }}$ century onwards, thereby contributing to the growth of the therapeutic market. Many of them, such as remedies for venereal diseases or sexual disorders, concern sexuality. These advertisements reveal that there was a consumption of medical products aimed at sexuality: the mechanisms of supply and demand served to integrate the history of medicine and sexuality into the broader market economy, which raises the question of the real extent of professionals' expertise - whether official or parallel - i.e. in fields where they purported to provide an effective response.

47 Cf. particularly on the reception of medical discourse and its limits, Barras 2005 and Sohn 1996.

48 Artières 2000 and 2003; Apitzsch 2006. 
Other sources surely remain to be discovered in the archives, and one can only hope for new investigations. Research tools do exist for the history of medicine, but they do not tend to focus particularly on archives dealing with sexuality. The guide to the Bibliothèque nationale de France (BnF, National Library of France), is particularly helpful for the excellent presentation it provides to its own collections (incunabula, theses, treatises and journals) ${ }^{49}$. The historical archives of the Bibliothèque interuniversitaire de Santé (BIUSante, Inter-Universitary Health Library) are extremely rich, surpassing the $\mathrm{BnF}$ for the $19^{\text {th }}$ and early $20^{\text {th }}$ centuries (and for foreign documents $)^{50}$. The library of the Academie nationale de Médecine also has an important archive constituted in large part by its first librarian Charles-Victor Daremberg, who was also a doctor, Hellenist and medical historian. Composed along classic history of science lines, Morton's Medical Bibliography provides an annotated inventory of over 8,000 major medical texts, from Antiquity to the 1980s, classifying them chronologically for each field of medicine ${ }^{51}$. The guide to scientific archives in France ${ }^{52}$, which inventories the personal archives of scientists from the $16^{\text {th }}$ to the $20^{\text {th }}$ century, includes a great number of doctors. And finally, the search engine Bora, for private archives kept in public services, lists some 15 or so doctors' archives. These results are bound to increase as more and more archives are donated and digitized ${ }^{53}$.

Digitization of documents facilitates access to them and accelerates searches by search engines. Twenty-five per cent of the scientific and technical corpus of the digital library Gallica concerns the medical sciences. Mandragore, the image database of the BnF's Manuscripts department, also includes a great number of images related to medical sciences. ${ }^{54}$ BIUSanté's Medic@ site makes part of the collection available in digital form: monographs, theses,

\footnotetext{
49 Boyer 2008.

50 Cf. http://www.bium.univ-paris5.fr/

51 Garrisson \& Morton 1991.

52 Charmasson 2008.

53 Cf. http://daf.archivesdefrance.culture.gouv.fr/sdx-222-daf-bora-ap/ap/

54 Cf. http://mandragore.bnf.fr/html/accueil.html
} 
dictionaries, periodicals and medical manuscripts and publications from the Middle Ages through the $19^{\text {th }}$ century ${ }^{55}$. Research by keyword can therefore be performed simultaneously on entire dictionaries and periodicals, or can be focused on parts of them. Various American and British institutions offer medical-history portals and a great number of digital resources, most notably the National Library of Medicine (NLM, Bethesda, Maryland, USA) ${ }^{56}$. In addition to bibliographic references and a range of catalogues, the NLM's website includes an image database containing nearly 70,000 portraits, photographs,

caricatures, posters and other pictorial representations from the $15^{\text {th }}$ to the $21^{\text {st }}$ century. London's Wellcome Library proposes a catalogue to - and in some cases the digitization of - its archives, which date from Antiquity to the present day: medical manuscripts, personal and scientific documents, professional journals, recipes, photographs and more. Its annex, Wellcome Images, allows for extremely advanced image searches ${ }^{57}$. The range of available sources and the new tools created for making use of them should sustain interest in the elaboration of a history of sexuality as seen through the prism of medical points of view. Forty years after the first pioneering research work about medicine and sexuality, the singularity of its development in France, particularly in comparison with American studies, can be highlighted. The orientation and time-scales of research into these issues are due to continuity between issues raised by historical demography, history of mentalities, women's and literary history, and by renewals inspired by gender and cultural history. From the study of theological - or judicial - sources - to those coming from medicine, a history of normative discourses about sexuality has been elaborated, and it has now been further enriched with lay representations and perceptions.

Translated from the French by Regan Kramer

55 Cf. http://www.bium.univ-paris5.fr/histmed/medica.htm

56 Cf. http://www.nlm.nih.gov/hmd/index.html

57 Cf. http://library.wellcome.ac.uk 


\section{Bibliography}

« Histoire et sexualité », 1974, Annales ESC, juillet/aout, p. 973-1057.

«Pudeurs médicales et pudeurs des souffrants », 2012, Histoire, médecine et santé.

APITZSCH Georges, 2006, Lettres d'un inverti allemand an Docteur Lacassagne. 1903. 1908, (edited with notes by Philippe Artières), Paris, EPEL.

ARIÈS Philippe \& André BÉJIN (eds), 1982, " Sexualités occidentales », Communications, 35 .

ARON Jean-Paul \& Roger KEMPF, 1978, Le pénis et la démoralisation de l'Occident, Paris, Grasset.

ARTIÈRES Philippe, 2000, Le livre des vies coupables. Autobiographies de criminels (18961909). Paris, Albin Michel.

ARTIÈRES Philippe \& Jean-François LAE 2003, Lettres perdues. Écritures et enfermement (XIXe-XXe siècles), Paris, Hachette-Littérature.

ARTIÈRES Philippe \& Emmanuel da SILVA (dir.), 2001, Michel Foucault et la médecine, Conference proceedings, L'Abbaye d'Ardenne, Paris, Éditions Kimé.

BARRAS Vincent, 2005, "La réception des innovations sanitaires dans l'espace domestique au XVIIIe siècle. L'exemple paradoxal de l'onanisme », in Olivier

FAURE \& Patrice BOURDELAIS (eds Les nomvelles pratiques de santé (XVIIIe-XXe siècles), Paris, Belin, p. 127-141.

BEJIN André 1990, Le nouveau tempérament sexuel. Essai sur la rationalisation et la démocratisation de la sexualité, Paris, Kimé.

BERGUES Hélène (ed.), 1960, La prévention des naissances dans la famille. Ses origines dans les temps modernes, Paris, PUF.

BERNOS Marcel \& Michèle BITTON, 2004, Femmes, Familles Filiations, Société et histoire, études réunies en hommage à Yvonne Knibiebler, Aix-en-Provence, Publications de l'Université de Provence.

BIENVILLE M.-D.-T. DE, 1980 (1886), De la nymphomanie ou Traité de la fureur utérine [re-edited by Jean-Marie Goulemot], Paris, Le Sycomore. (English translation: Nymphomania, or Treatise on Uterine Fury, trans. 1771).

BINET Alfred, 2001 [1887] , Le fétichisme dans l'amour, Paris, Payot [re-edited by André Béjin].

BONELLO Christian, 1984, «Le discours médical sur l'homosexualité en France à la fin du XIXe siècle. Des années 1870 aux années 1900 », doctoral thesis, University of Paris VII, supervised by Michelle Perrot.

BONNET Marie-Jo, 1981, Un choix sans équivoque, Paris, Denoël-Gonthier. 
BORIE Jean, 1973, Le tyran timide, essai sur le naturalisme de la femme au XIXe siècle, Paris, Klincksiek.

BOYER Anne, 2008, with Caroline Rives, Des sources pour l'bistoire de la médecine: Guide, Paris, Bibliothèque nationale de France.

BRANCHER Dominique, 2012, «Splendeurs et misères des figures de style. Pudeurs du discours médical aux XVIe et XVIIe siècles ", Histoire, médecine et santé, 1, p. 1934.

BURGUIÈRE André, 1974, «Introduction dossier Histoire et sexualité », Annales ESC, 4, p. 973-974.

CARDON Patrick, 2008, Discours littéraires et scientifiques fin-de-siècle. Autour de MarcAndré Raffalovich. Paris, Orizons.

CAROL Anne, 2002, « Les médecins et la stigmatisation du vice solitaire (fin XVIIIeXIXe siècle) », Revue d'bistoire moderne et contemporaine, 49/1, p. 156-172.

CHAPERON Sylvie, 2002, "L'histoire contemporaine des sexualités en France », Vingtième siècle, p. 47-59.

—, 2012a, Les origines de la sexologie 1850-1900, Paris, Payot.

—, 2012b, «Le trône des plaisirs et des voluptés. Anatomie politique du clitoris de l'Antiquité à la fin du XIXe siècle » Cabiers d'bistoire, Revue d'bistoire critique, 118, janvier-mars, p. 41-60.

CHARMASSON Thérèse, 2008, with Catherine GAZIELLO, Marion DANIEL \& Carole ROTA-TRÉGUIER (eds), Les Archives des scientifiques, XVIe-XXe siècle. Guide des fonds conservés en France, Paris, Éditions du Comité des travaux historiques et scientifiques.

CORBIN Alain, 1978, Les Filles de noce: misère sexuelle et prostitution (XIXe-XXe siècle), Paris, Aubier Montaigne. [English translation by Alan Sheridan Women for Hire: Prostitution and Sexuality in France after 1850, (1996)]

—, 1984, «La petite bible des jeunes époux », L'Histoire, 63, p.70-75, reprinted in Le temps, le désir et l'horreur. Essais sur le XIXe siècle, Paris, Aubier, 1991.

—, 2000, Historien du sensible, entretiens avec Gilles Heuré, Paris, La Découverte.

—, 2003, «Les principales étapes de l'histoire du sexe en Occident », in Odile

REDON, Line SALLMANN \& Sylvie STEINBERG (eds Le désir et le goût. Une autre bistoire (XIIIe-XVIIIe siècle), Vincennes, PUV.

—, 2007, L'harmonie des plaisirs. Les manières de jouir du siècle des Lumières à l'avènement de la sexologie Paris, Éditions Perrin.

COULMONT Jean Baptiste \& Marianne BLIDON, 2010, « De la sociabilité au genre et à la sexualité. Entretien avec Michel Bozon sur les étapes d'un parcours 
sociologique », Genre, sexualité \& société, 4, [consulted online 19 October 2012].

URL: http://gss.revues.org/index1628.html

DARMON Pierre, 1977, Le mythe de la procréation à l'âge baroque, Paris, J.J. Pauvert.

—, 1979, Le tribunal de l'impuissance, virilité et défaillances conjugales dans l'ancienne France, Paris, Seuil.

—, 1983, Mythologie de la femme dans l'ancienne France, XVTe-XVIIIe siècle, Paris, Seuil.

DELON Michel, 1980, «Le prétexte anatomique », Dix-buitième siècle, 12, p. 35-49.

ELIAS Norbert, 1973 (1re éd., 1939), La civilisation des moeurs, Paris, Calmann-Lévy, coll. « Pocket Agora ».

FISCHER Jean-Louis, 1991, "La callipédie, ou l'art d'avoir de beaux enfants », Dixhuitième siècle, 23, p. 141-158.

FLANDRIN Jean-Louis, 1970, L'église et le contrôle des naissances, Paris, Flammarion.

—, 1981, Le sexe et l'Occident. Évolutions des attitudes et des comportements, Paris, Seuil.

FOUCAULT Michel, 1976, La volonté de savoir, bistoire de la sexualité, tome I, Paris,Gallimard. [English translation by Robert Hurley: The Will to Knowledge, The History of Sexuality, Volume 1, , New York. Pantheon Books, 1928.)

—, 1982, «Le combat de la chasteté », Communications, 35, p. 15-25.

GARRISSON Fielding Hudson \& Leslie MORTON, 1991 [5e éd.], Morton's Medical Bibliography: An annotated check-list of texts illustrating the bistory of medecine, Aldershot, Scholar Press.

GOULEMOT Jean-Marie (ed.), 1980, « Représentations de la vie sexuelle », special number Dix-buitième siècle, 12.

GOULEMOT Jean-Marie, 1980, «Fureurs utérines », Dix-buitième siècle, 12, p. 97-111.

GUICCIARDI Jean-Pierre, 1980, «L'hermaphrodite et le prolétaire », Dix-buitième siècle, 12, p. 112-128.

HALPERIN David, 2000, Saint Foucault, Paris, EPEL [Translated from: Saint Foucault: Towards a Gay Hagiography, New York, Oxford University Press, 1995].

HANAFI Nahema, 2012, Le frisson et le baume. Souffrantes et soignantes au siècle des Lumières, Doctoral thesis, Université Toulouse II Le Mirail.

HARVEY Karen, 2010, « Le siècle du sexe ? Genre, corps et sexualité au XVIIIe siècle (vers 1650-vers 1850) », in Violaine SEBILLOTTE CUCHET \& Sylvie STEINBERG (eds), «Érotiques », CLIO. Histoire, femmes et sociétés, 31, p. 207-238.

JONES Colin, 1987, " 'New medical history' in France: The view from Britain », French Historian, 2, p. 3-14. 
KRAFFT-EBING Richard von, 2010, Les formes du masochisme, [re-edited by André Béjin,] Paris, Payot.

_, 2011, Sadisme de l’homme; sadisme de la femme, [re-edited by André Béjin], Paris, Payot.

KNIBIEHLER Yvonne, 1976a, «Les médecins et la « nature féminine » au temps du Code civil », Annales. Économies, Sociétés, Civilisations, 31/4, p. 824-845.

—, 1976b, «Le discours médical sur la femme: constantes et ruptures », Romantisme, vol. $6, \mathrm{n}^{\circ} 13$, p. 41-55.

—, 1980, "Les médecins et l'amour conjugal au XIXe siècle », in Aimer en France 1760-1860, Clermont-Ferrand, Presses Universitaires de Clermont-Ferrand, p. 357-366.

—, 1983, La femme et les médecins, Paris, Hachette.

—, 1996, "L'éducation sexuelle des filles au XXe siècle », in Gabriel HOUBRE (ed.) «Le temps des jeunes filles », Clio. Histoire, femmes et sociétés, 4, p. 139-160.

—, 2010, Mémoires d'une féministe iconoclaste, Paris, Hachette.

KNIBIEHLER Yvonne \& Catherine MARAND-FOUQUET, 1980, Histoire des mères, du Moyen-âge à nos jours, Paris, Montalba.

LANTERI-LAURA Georges, 1979, Lectures des perversions. Histoire de leur appropriation médicale, Paris, Masson.

LAQUEUR Thomas, 1989, "Amor Veneris, vel Dulcedo Appeletur », in Michel FEHER, Ramona NADDAFF \& Nadia TAZI (eds), Fragments for a History of the Human Body, New York, Zone books, p. 91-131.

-, 2005, Le sexe en solitaire. Contribution à l'bistoire culturelle de la sexualité, Paris, Gallimard [Translated from: Solitary Sex. A Cultural History of Masturbation, Urzone Inc., 2003].

LEBRUN François, 1985, La vie conjugale sous l'Ancien Régime, Paris, Armand Colin.

LEJEUNE Philippe, 1974, "Le “dangereux supplément": lecture d'un aveu de Rousseau », Annales ESC, 4, p. 1009-1022.

LOMBROSO Cesare, 1991, La femme criminelle et la prostituée, [re-edited by Pierre Darmon], Grenoble, J. Million.

MONTER E. William, 1974, «La sodomie à l'époque moderne en Suisse romande », Annales ESC, 4, p. 1023-1033.

MUCHEMBLED Robert, 2005, L'orgasme et l'Occident, Paris, Le Seuil.

MURAT Laure, 2006, La loi du genre. Une histoire culturelle du troisième sexe, Paris, Fayard. 
NOONAN John T., 1966, Contraception. A bistory of its Treatment by the Catholic Theologians and Canonists, Cambridge, Mass., The Belknap Press of Harvard University Press.

OOSTERHUIS Harry 2000, Stepchildren of Nature. Krafft-Ebing, Psychiatry and the Making of Sexual Identity, Chicago, University of Chicago Press.

PARK Katharine, 1997, "The Rediscovery of the Clitoris. French Medicine and the Tribade, 1570-1620 ", in David HILLMAN \& Carla MAZZIO (eds), The Body in Parts. Fantasies of Corporeality in Early Modern Europe, New York, Routledge, p. 171193.

PESTRE Dominique, 1995, "Pour une histoire sociale et culturelle des sciences, nouvelles définitions, nouveaux objets, nouvelles pratiques », Annales HSS, 3, p. 487-522.

PILLOUD Séverine, 2008, Les mots du corps. L'expérience de la maladie dans les consultations épistolaires adressées au Dr Samuel Auguste Tissot (1728-1797), Doctoral thesis, Faculté des Lettres de Lausanne, Lausanne.

PORTER Roy, 1985, "The patient's view: doing medical history from below », Theory and society, 14, p. 175-198.

PORTER Roy \& Andrew WEAR, 1987, "Introduction », in Roy PORTER \& Andrew WEAR, Problems and methods in the history of medicine, New York, Croom Helm.

PORTER Roy \& Mikulas TEICH (eds), 1994, Sexual knowledge, sexual science: the history of attitudes to sexuality, Cambridge, Cambridge University Press.

REBREYEND Anne-Claire, 2005, «Comment écrire l'histoire des sexualités au XXe siècle ? Bilan historiographique comparé français/anglo-américain », in Sylvie

CHAPERON \& Agnès FINE (dir.), "Utopies sexuelles », Clio. Histoire, femmes et sociétés, 22, p. 185-209.

REVENIN Régis, 2007, "Les études et recherches lesbiennes et gays en France (1970-2006) », Genre et histoire, 1 [online].

ROSARIO Vernon A., 2000, L'irrésistible ascension du pervers entre littérature et psychiatrie, Paris, EPEL [Translation by Guy le Gaufey of The Erotic Imagination: French Histories of Perversity, Oxford, Oxford University Press, 1997].

SOHN Anne-Marie, 1996, Chrysalides. Femmes dans la vie privée (XIXe-XXe siècles), Paris, Publications de la Sorbonne.

STENGERS Jean \& Anne VAN NECK, 1998, Histoire d'une grande peur: la masturbation, Le Plessis-Robinson, Inst. Synthélabo pour le progrès de la connaissance. 
STOLBERG Michael, 2000, "An Unmanly Vice: Self-Pollution, Anxiety, and the Body in the Eighteenth Century ", Social History of Medicine, 13/1, p. 1-21.

TAMAGNE Florence, 2000, Histoire de l'homosexualité en Europe, Berlin, Londres, Paris, 1919-1939. Paris, Seuil.

—, 2007, «Écrire l'histoire des homosexualités en Europe: XIXe-XXe siècles », Revue d'histoire moderne et contemporaine, 53/4, p. 7-31.

TARCZYLO Théodore, 1980, "Prêtons la main à la nature... Lire l'onanisme de Tissot », Dix-buitième siècle, 12, p. 79-96.

—, 1983, Sexe et liberté au siècle des Lumières, Paris, Presses de la Renaissance.

TEYSSEIRE Daniel, 1995, Obèse et impuissant, Grenoble, Jérôme Millon.

VAN USSEL Jos, 1972, Histoire de la répression sexuelle, Paris, Robert Laffont [translated from: Sexualunterdrückung, Hamburg, Reinbek b. 1970].

VANDELAC Louise, 1977, Les Cabiers du GRIF, 17/1, p. 103-104.

VELLE Karel, 1998, "Pour une histoire sociale et culturelle de la médecine ", Sartoniana, 11, p. 156-191.

WENGER Alexandre, 2005, « Lire l'Onanisme. Le discours médical sur la masturbation et la lecture féminine au XVIIIe siècle », in Sylvie CHAPERON \& Agnès FINE (eds), "Utopies sexuelles », Clio. Histoire, femmes et sociétés, 22, p. $227-$ 243. 